\title{
Efficacy of wood vinegars for the control of Sclerotium rolfsii affecting tomato (Solanum lycopersicum L.)
}

\author{
Lucia M. Borines" ${ }^{1 *}$, Merlita M. de la Cruz', Fely Cañete', Zenaida Gonzaga', \\ Othello Capuno', Gordon Rogers', Sandra McDougall ${ }^{2}$ and Len Tesoriero ${ }^{3}$
}

\begin{abstract}
Wood vinegar is claimed to be pesticidal by several researchers but its bioefficacy data on specific pests are lacking. This study evaluated 17 wood vinegars against $S$. rolfsii causing sclerotium wilt in tomato in vitro and in vivo. Eleven out of 17 wood vinegars showed direct inhibition to $S$. rolfsii at $2 \%$ concentration. These include wood vinegars from bamboo, banaba, cacao, caimito, ipil-ipil, lumboy, madre de cacao, malunggay, mango, panyawan and rice hull. These wood vinegars varied in their effectiveness in inhibiting the colony growth of $S$. rolfsii in vitro, with wood vinegar from ipil-pil showing the highest inhibition to the fungal growth followed by wood vinegar from lumboy. Wood vinegar from ipil-ipil however was the most phyto-toxic to tomato. The wood vinegar from lumboy, is promising since it was one of the most effective in reducing the disease severity in inoculated seedlings and was one of the least phyto-toxic. The wood vinegars from malunggay and panyawan, although not very effective in vitro were the most effective in reducing the disease severity in inoculated tomato plants and retained their effectiveness longer. Lower concentrations of the wood vinegars as a whole $(0.2 \%)$ was the most effective in reducing sclerotium wilt severity over time, even though this concentration showed no direct inhibition to the fungus in vitro. This finding implies that wood vinegar may possess another mode of action in controlling the disease aside from the direct antifungal activity, which could be induction of resistance in plants to specific diseases.
\end{abstract}

Keywords: pyroligneous acid, Southern blight mokusaku tomato antifungal

\footnotetext{
${ }^{1}$ Visayas State University, Visca, Baybay City, Leyte, Philippines

${ }^{2}$ Department of Primary Industries (DPI), Australia, NSW, Australia

${ }^{3}$ Applied Horticultural Research, Sydney, NSW Australia
}

\footnotetext{
* Corresponding Author. Address: Department of Pest Management, Visayas State University, Visca, Baybay City, Leyte, 6521-A Philippines; Email:lucyborines@vsu.edu.ph DOI: $10.32945 /$ atr39sb4.2017
} 
Efficacy of wood vinegars for the control of Sclerotium rolfsii affecting tomato

\section{INTRODUCTION}

Tomato (Solanum lycopersicum L.) is cultivated globally for its fleshy fruit, special nutritive value and protective properties (Hadizadeh et al 2009). It is the world's largest vegetable crop after potato and it tops the list of canned vegetables (Omara 2010). Tomato crops have reduced yield due to number of pathogenic diseases. Such diseases are caused by fungi, bacteria, viruses and nematodes, which develop through soil-borne or above-ground infections, and in some instances are transmitted through insect feeding (Wani 2011).

Sclerotium wilt caused by Sclerotium rolfsii Sacc. is one of the major and destructive soil borne phytopathogenic fungi that affect tomato and several other crops (Fouzia \& Saleem 2005, Kokub et al 2007, Maurya et al 2010). It produces a considerable mass of mycelia and sclerotial bodies on the plant's surface. It can cause damping-off of seedlings, stem canker and crown blight, root, crown, bulb, tuber and fruit rots. All these symptoms results in significant yield loss in tomato (Rakh et al 2011). The sclerotia can survive in soil for long periods, making the pathogen very difficult to control. It can tolerate biological and chemical degradation due to the presence of melanin in the outer membrane (Ilan 1975).

Several studies have shown the effectiveness of various fungicides for the control of S. rolfsii (Johnson \&d Subramanyam, 2000 Palaiah 2002). Fungicides, however can be hazardous to the environment and cause side effects on non-target organisms. Discovery of alternative disease control methods using natural products that are non- or less toxic are therefore necessary. Wood vinegar is identified as a potential natural product for disease control.

Wood vinegar, also called pyroligneous acid, pyrolysis oil, pyrolysis liquid, wood liquid, liquid smoke, liquid wood, bio-oil, bio-crude oil and wood distillate (Zulkarami et al 2011) is an amber liquid which is a by-product from charcoal production, a condensate from the combustion of fresh wood burning in airless conditions (Udomporn et al 2010). It has been used as a traditional remedy by the Japanese for over 400 years (Mu et al 2003). Wood vinegar is said to be composed of more than 200 chemicals such as: sugars; acids including acetic acid and carboxylic acid; alcohols including methanol; formaldehyde, ethyl-valerate, phenols, aldehydes, ketones, esters, furans and pyran derivatives, nitrogen compounds and tar compounds (Fengel \& Wegener 1984, Kim et al 2008, Ninomiya et al 2004, Burnette 2010). Wood vinegar extract is usually obtained from species used to make charcoal (Cai et al 2012) and other alternatives such as sugarcane bagasse (Saccharum officinarum L., Poaceae, Zandersons et al 1999).

Wood vinegar has been used in a variety of processes, such as industrial, livestock, household and agriculture products. It was reported to improve soil quality, eliminate pests, and accelerate or inhibit plant growth (Apai \& Thongdeethae 2001). Wood vinegar was reported to replace chemical pesticides for organic farming purposes. It was demonstrated to have low mammalian toxicity, lack neurotoxicity, have low persistence in the environment, and have high biodegradability (Céspedes et al 2000).

Pyroligneous acid was reported to have bactericidal, fungicidal, and insecticidal activity (Mu, Uehara \& Furuno 2003). Several studies had proven the antifungal activity of wood pyroligneous acid, such as towards wood decay fungi Trametes versicolor and Tyromyces palustris (Nakai et al 2005); Curvularia. lunata, 
Bipolaris,Cercospora oryzae, Fusarium semitectum, and Alternaria. padwickii, causing dirty panicle disease of rice (Chuaboon, Ponghirantanachoke \& Athinuwat 2016); Rhizoctonia solani and Sclerotinia sclerotiorum affecting greenhouse cucumbers (Sabere et al 2013); Alternaria mali, the agent of Alternaria blotch of apple (Jung 2007); Phytophthora capsici, Fusarium oxysporium, and Pythium splendens (Hwang et al 2005). Its' antibacterial property was reported against Ralstonia solanacearum (Hwang et al 2005), dermatitis bacteria (Rakmai et al 2009). Its' insecticidal activity was reported against termites (Yatagai et al 2002, Adfa et al 2017); against insect damage rating in Chinese kale (Pangnakorn et al 2007); Spodoptera litura (Fereira et al 2013); Sitophilus zeamays (Rahmat et al 2014); Spodoptera frugiperda (Ferreira et al 2013); Nilaparvata lugens and Laodelphax striatellus (Kim et al 2008); and housefly Musca domestica (Pangnakorn and Kanlaya 2014). Furthermore, acetic acid, furfural and ethersoluble (mainly aldehydes, ketones, lignin monomers) and ether-insoluble ("wood syrup") fractions of the water extract of wood vinegar induced a clear repellent effect on snails (Hagner et al 2015).

The Department of Agriculture Regional Office 8 (DA-RF08) through the Regional Crop Protection Center (RCPC) at the Abuyog Experiment Station in Leyte had implemented the wood vinegar project and established wood vinegar plants with funds from the High Value Crops Development Program- Organic Agriculture Program (HVCDCP-OAP) and TechGen, a company from Cavite which specializes in different methods and techniques in urban farming (Calesterio accessed, January, 2018). It has maintained a wood vinegar plant and distributed 1,750 liters of wood vinegar to 340 farmers. Under the OAP of the Department of Agriculture, wood vinegar is promoted as a fertilizer, insect repellant, soil conditioner, organic insecticide and fungicide.

The bioefficacy data on the effectiveness of these wood vinegars against local pests and diseases, however is very much lacking. This study was therefore conducted to evaluate the efficacy of wood vinegar from different wood sources against Sclerotium rolfsii, one of the major disease affecting tomato, to identify the most effective wood vinegar source and determine the concentration that is/are non-toxic to tomato.

\section{MATERIALS AND METHODS}

\section{Procurement of Materials}

Wood Vinegars were procured from RCPC at the Abuyog Experiment Station in Balinsasayao, Abuyog, Leyte. Seventeen different kinds of wood vinegars were obtained from: panyawan (Tinosphora rumphii), banaba (Lagerstroemia speciosa), cacao (Theobroma cacao), malunggay (Moringa oleifera), bamboo (Bambusa vulgaris), tigbao (Saccharum spontaneum), madre de cacao (Gliricidia sepium), lumboy (Syzygium cumini), mango (Mangifera indica), rice hull (Oryza sativa), rambutan (Nephelium lappaceum), caimito (Chrysophyllum cainito), rubber (Hevea brasiliensis), gmelina (Gmelina arborea), libas (Spondias pinnata), coconut (Cocus nucifera) and ipil-ipil (Leucaena leucocephala). Tomato seeds (Diamante Max) were procured from the local market. 
Efficacy of wood vinegars for the control of Sclerotium rolfsii affecting tomato

\title{
S. rolfsii Isolation and In vitro Assay
}

S. roflsii was isolated from infected tomato using PDA medium and using standard isolation techniques. The different wood vinegars were evaluated for possible antimicrobial property against $S$. rolfsii in vitro. Three sets of in vitro assays were done. The first assay was a preliminary evaluation and used 17 wood vinegars at three different concentrations: $0.02 \%, 0.2 \%$ and $2.0 \%$. The wood vinegars which did not show inhibition in the first assay were not included in the second assay. The second assay used only 11 wood vinegars that initially showed inhibition to $P$. palmivora and assayed against the pathogen at four different concentrations: $0.2 \%$, $0.5 \% 1.0 \%$ and $2.0 \%$.

In the preliminary assay, three day old plate culture of S. rolfsii was aseptically cut with sterile $10 \mathrm{~mm}$ cork borer and three agar discs of the pathogen was transferred into the plated PDA amended with the different wood vinegars at three concentrations with three replications. Three agar discs were placed equidistantly on each plate. In the second assay, only one agar disc was placed on each plate. The treatments were arranged in two factor factorial in CRD with 3 replications per treatment. Factor $\mathrm{A}$ were the different concentrations and Factor $\mathrm{B}$ were the different wood vinegars.

The colony diameter of the fungus was measured at $72 \mathrm{~h}$ after inoculation in the first preliminary trial and at 24,48 and $72 \mathrm{~h}$ after inoculation in the second trial. Sterile distilled water was included as control in each assay.

\section{Wood Vinegar Toxicity Test}

Toxicity test was done under screenhouse condition using nine wood vinegars from: banaba, cacao, ipil-ipil, lomboy, madre de cacao, malunggay, mango, panyawan, rice hull and tigbao and at four different concentrations, namely: $0.2 \%$, $0.5 \%, 2 \%$ and $20 \%$. Tomato seeds (Diamante Max) were grown in a seedling tray for two weeks and transferred into pots with sterilized soil. One week after transplanting, $15 \mathrm{~mL}$ of the different wood vinegars were applied to the tomato seedlings as drench and the plants were observed daily for possible signs of toxicity to the seedlings. The treatments were arranged in CRD with 3 replications per treatment. The toxicity rating scale is shown below:

Toxicity rating
1
2
3
4
5

\author{
Description \\ No wilting \\ Slightly wilted \\ Moderately wilted \\ Highly wilted \\ Extreme wilting or plant is dead
}

\section{In vivo Evaluation of Wood Vinegar Against S. rolfsii}

Tomato seeds were sown in seedling tray with sterilized soil and transferred into pots in the screenhouse. Three weeks old tomato seedlings were inoculated with one week old culture of $S$. rolfsii. Agar $(40 \mathrm{~mm} \times 30 \mathrm{~mm})$ containing the fungal mycelia and sclerotia were introduced to the soil near the base of the seedling. One day after inoculation, $20 \mathrm{~mL}$ of four concentrations $(0.2 \%, 0.5 \%, 1.0 \% \& 2 \%)$ of 11 wood vinegars (bamboo, banaba, cacao, ipil-ipil, lomboy, madre de cacao, 
malunggay, mango, panyawan, rice hull \& tigbao) were applied as a drench near the roots of the plants. The treatments were arranged in two factor factorial design in RCBD with three replicate plants per treatment combination. Factor A were the different concentrations while factor $B$ were the different wood vinegars. Disease severity rating was gathered regularly using the same rating scale used in the toxicity test.

\section{RESULTS AND DISCUSSION}

\section{In-vitro Evaluation of Wood Vinegars against S. rolfsii}

Among the 17 wood vinegars evaluated against S. rolfsii in the preliminary trial, 11 showed inhibition against the fungus $72 \mathrm{~h}$ after inoculation. They were: bamboo, banaba, cacao, caimito, ipil-ipil, lumboy, madre de cacao, malunggay, mango, panyawan and rice hull. Among the three concentrations used, only $2.0 \%$ showed inhibition of the pathogen. The lower concentrations (ie, $0.02 \%$ \& $0.2 \%$ ) did not inhibit the fungus (Table 1 ).

Table 1. Colony Diameter $(\mathrm{cm})$ of S. rolfsii as affected by different wood vinegars and concentration at 3 days after inoculation. (Preliminary Trial)

\begin{tabular}{|c|c|}
\hline Treatments & 72 Hours \\
\hline \multicolumn{2}{|c|}{ Factor A - Wood Vinegar } \\
\hline Bamboo & $4.57^{b}$ \\
\hline Banaba & $4.77^{b}$ \\
\hline Cacao & $4.74^{b}$ \\
\hline Caimito & $4.90^{\mathrm{b}}$ \\
\hline Coconut & $5.27^{\mathrm{ab}}$ \\
\hline Gmelina & $5.02^{\mathrm{ab}}$ \\
\hline Ipil-ipil & $4.90^{\mathrm{b}}$ \\
\hline Libas & $5.02^{\mathrm{ab}}$ \\
\hline Lomboy & $4.61^{\mathrm{b}}$ \\
\hline Madre de Cacao & $4.68^{b}$ \\
\hline Malunggay & $4.68^{b}$ \\
\hline Mango & $4.60^{b}$ \\
\hline Panyawan & $4.92^{\mathrm{b}}$ \\
\hline Rambutan & $5.22^{\mathrm{ab}}$ \\
\hline Rice hull & $4.50^{\mathrm{b}}$ \\
\hline Rubber & $4.96^{\mathrm{ab}}$ \\
\hline Tigbao & $4.97^{\mathrm{ab}}$ \\
\hline $\mathrm{SDH} 20$ & $5.76^{a}$ \\
\hline \multicolumn{2}{|c|}{ Factor B - Concentration } \\
\hline $0.02 \%$ & $50.19^{a}$ \\
\hline $0.20 \%$ & $50.81^{a}$ \\
\hline $2.00 \%$ & $45.63^{b}$ \\
\hline$A$ & ** \\
\hline B & ** \\
\hline$A B$ & ns \\
\hline CV\% & 9.77 \\
\hline
\end{tabular}


Efficacy of wood vinegars for the control of Sclerotium rolfsii affecting tomato

The 11 wood vinegars that showed inhibition in the preliminary trial were reevaluated and the results are shown in Table 2 and Figure 1. All wood vinegars at 0.2 and $0.5 \%$ showed no inhibition to $S$. rolfsii from 24 to $72 \mathrm{~h}$ after inoculation but some inhibited the fungus at $1 \%$ and $2 \%$. After $24 \mathrm{~h}, 1 \%$ ipil-ipil already showed inhibition of the fungus which lasted until the last observation period (72h). After $48 \mathrm{~h}, 1 \%$ lumboy also showed inhibition of the fungus aside from ipil-ipil which lasted to $72 \mathrm{~h}$. When the concentration was increased to $2 \%$, after $24 \mathrm{~h}$, six wood vinegars, namely, banaba, cacao, Ipil-ipil, lumboy, madre de cacao and rice hull produced significantly smaller colony diameter of the fungus. After $48 \mathrm{~h}$ bamboo also showed inhibition aside from the six earlier mentioned. The seven wood vinegars retained their inhibitory property at $72 \mathrm{~h}$ after inoculation.

These trials showed that the almost all of the effective wood vinegars increased their inhibitory property against $S$. rolfsii when the concentration was increased to $2 \%$. A higher concentration may already be phytotoxic to the plants, so the different wood vinegar concentrations were initially applied to the plants without pathogen inoculation to determine their phytotoxicity.

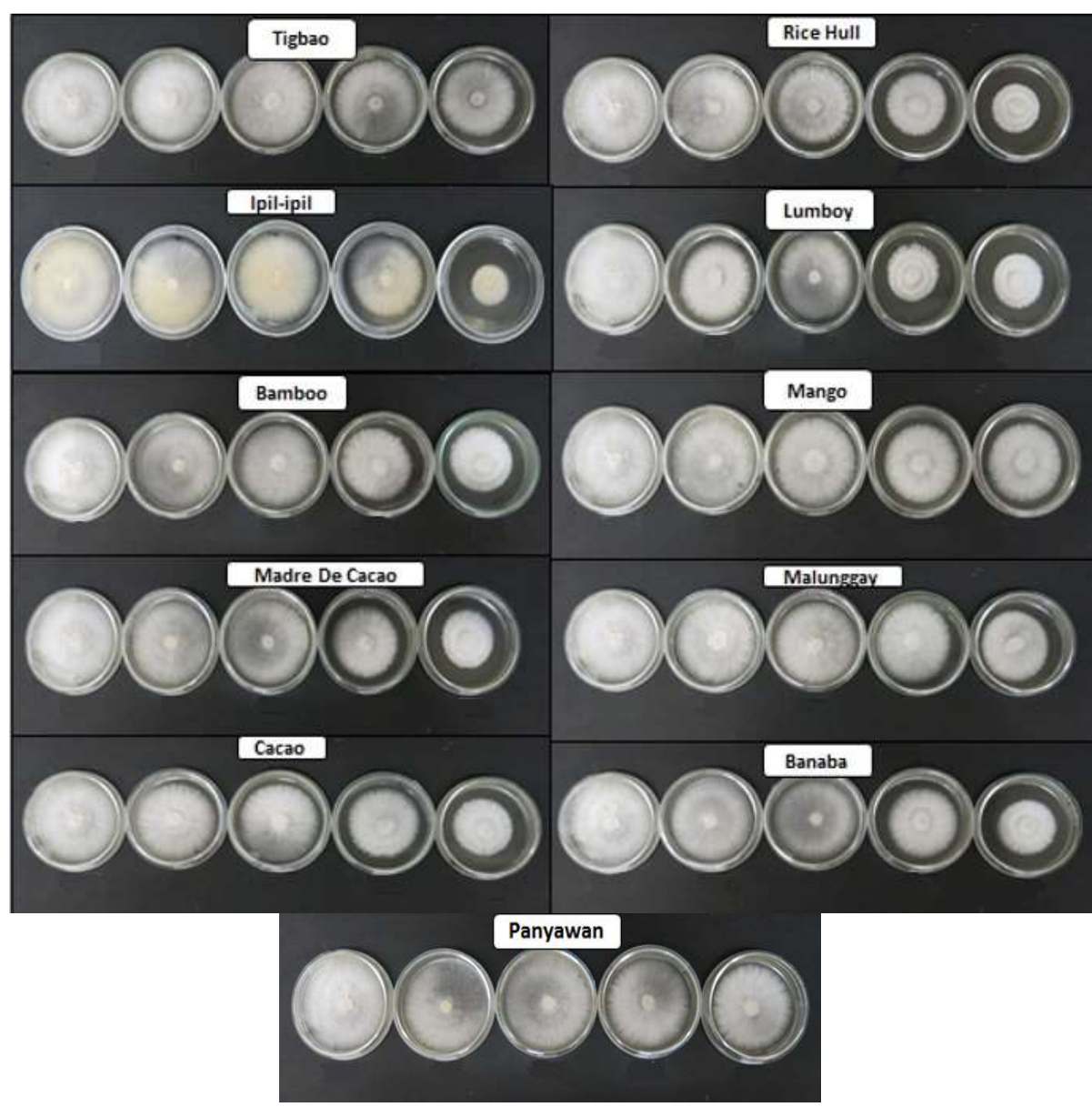

Figure 1. Second in vitro evaluation of wood vinegars at different concentrations against $\mathrm{S}$. rolfsii (2nd trial). From left to right for each wood vinegar: sterile distilled water (control), $0.2 \%$, $0.5 \%, 1.0 \%$ and $2.0 \%$. 
Borines et al

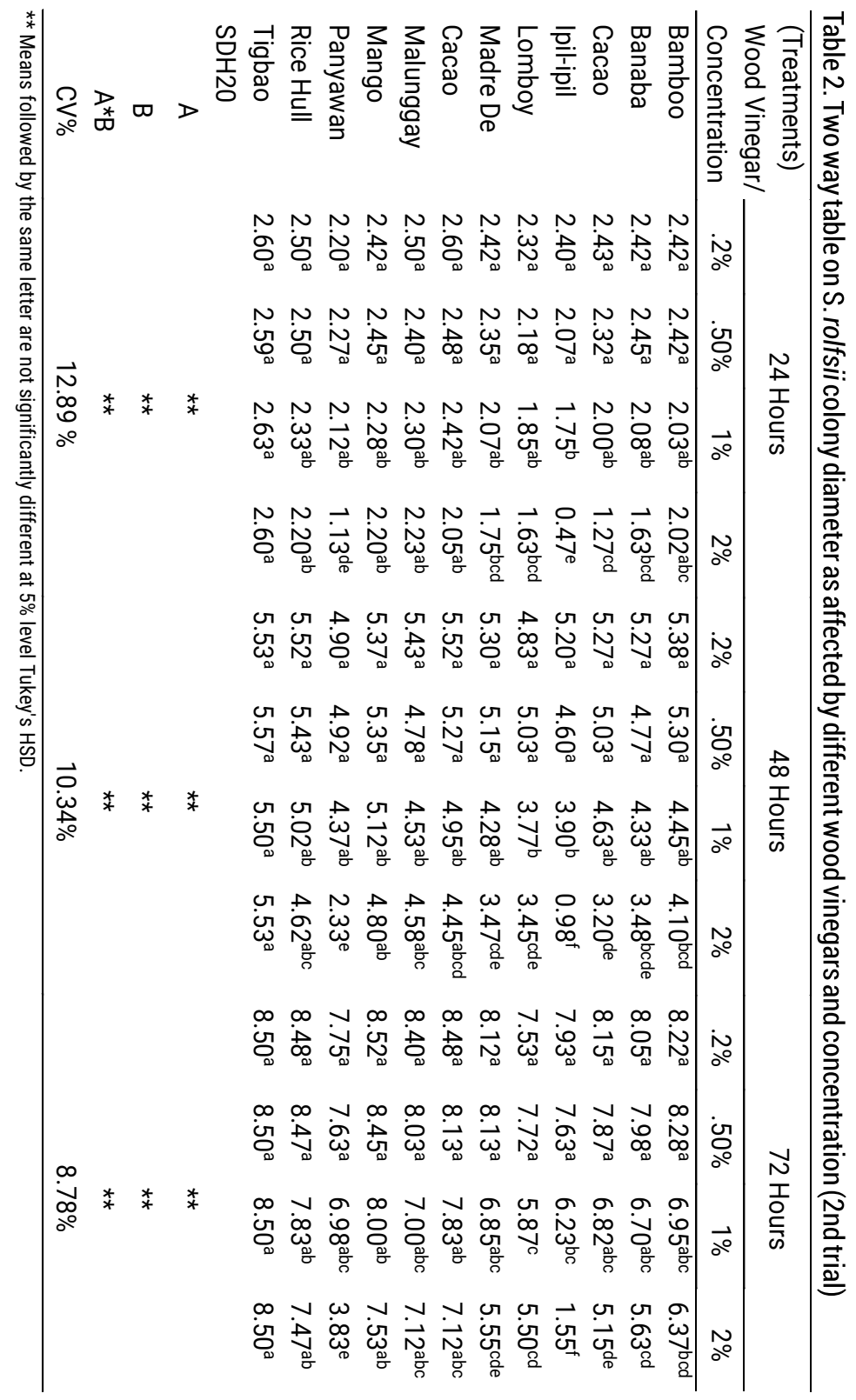


Efficacy of wood vinegars for the control of Sclerotium rolfsii affecting tomato

\section{Wood Vinegar Phytotoxicity Test}

Wood vinegar phytotoxicity test results is shown in Table 3. Toxicity of the wood vinegar to tomato was manifested by a much reduced lower stem diameter which caused damping off of the plants and ultimate wilting (Figure 3). It also caused burning of the leaves when hit by the wood vinegar.

Wood vinegar from ipil-ipil, provided the best growth inhibition to $S$. rolfsii in vitro was also the most toxic to tomato seedlings (Table 3 ). At $0.5 \%$ it already has a toxicity rating of 3 at $24 \mathrm{~h}$ and rating of 5 at $72 \mathrm{~h}$. There were wood vinegars however that inhibited the fungus at $2 \%$ in the in vitro trial but were are not phytotoxic (toxicity rating $=1.0$ ) at $2 \%$ at $72 \mathrm{~h}$ ) such as banaba, lumboy and madre de cacao. lumboy, particularly was already inhibitory at $1 \%$ but and not phytotoxic even at a higher concentration (2\%). Bamboo, cacao and tigbao were not phytotoxic at $2 \%$ after $72 \mathrm{~h}$.

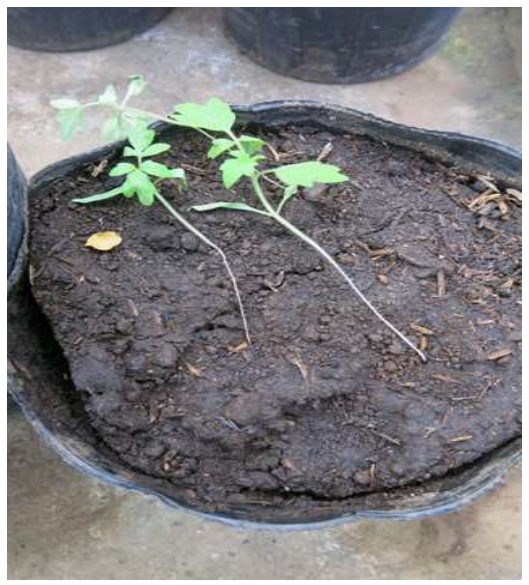

Figure 3. Symptom of wood vinegar phytotoxicity, ie, narrowing of the base of tomato seedlings 
Borines et al
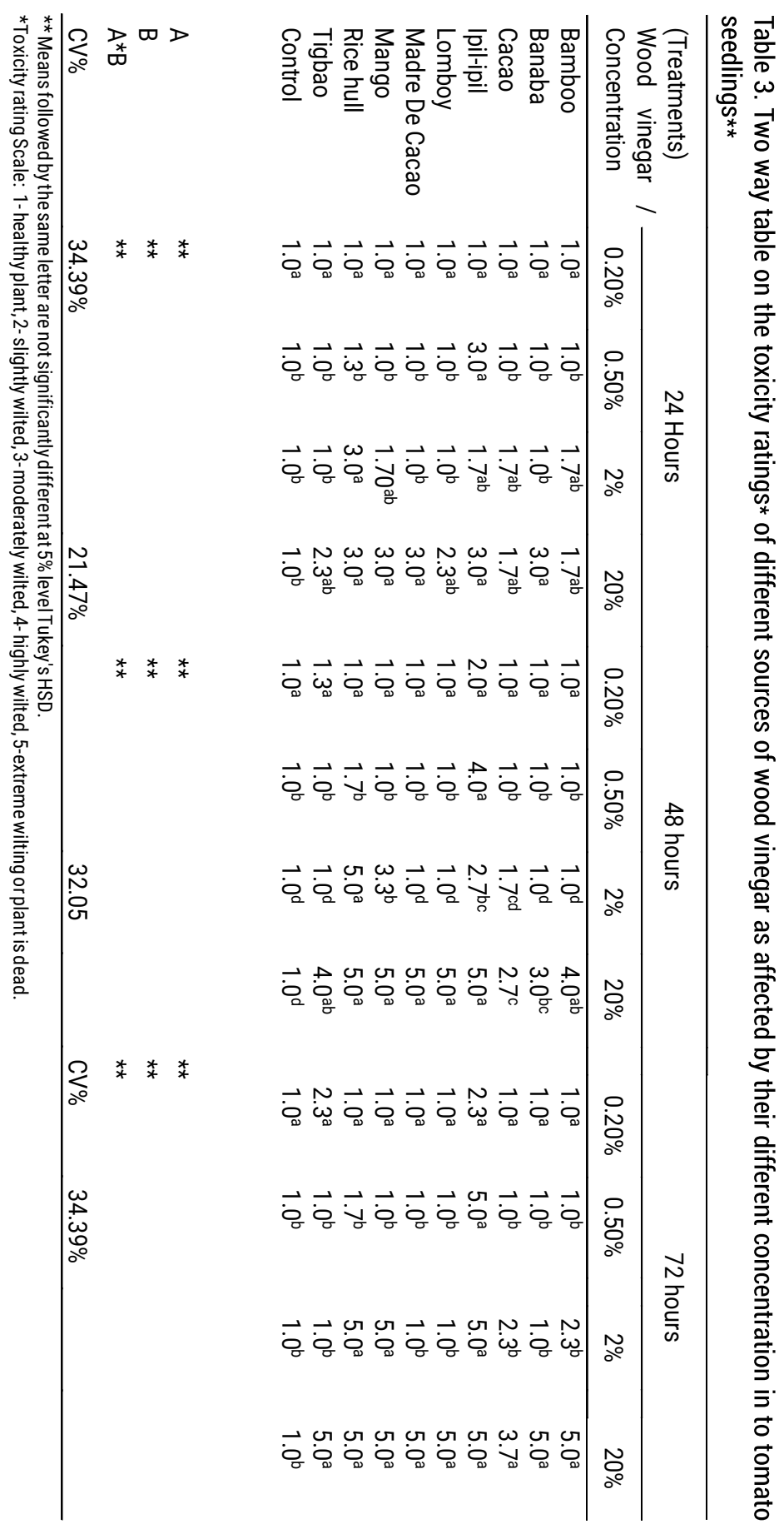
Efficacy of wood vinegars for the control of Sclerotium rolfsii affecting tomato

\section{Efficacy of Wood Vinegars Against Tomato Sclerotium Wilt}

Four different concentrations of wood vinegar were evaluated against S. rolfsii in inoculated tomato seedlings. After the first day of treatment, four wood vinegars produced smaller disease severity ratings, namely: bamboo, madre de cacao, malunggay and panyawan (Table 4). The effectiveness of bamboo, ipil-ipil and rice hull lasted only three days, lumboy for four days and madre de cacao lasted five days. Malunggay and panyawan remained effective for nine days. On the second day, ipil-ipil, lumboy and rice hull had also reduced the disease severity ratings. Mango produced smaller disease severity ratings during the $3^{\text {rd }}$ and $4^{\text {th }}$ days. Among the wood vinegars, malunggay and panyawan are considered the most effective wood vinegar in controlling sclerotium wilt because they remained effective for nine days.

When the disease severity was plotted against time, (Figure 3) all wood vinegars showed slower increase of disease over time with malunggay, panyawan and lumboy producing the slowest disease progression over time.

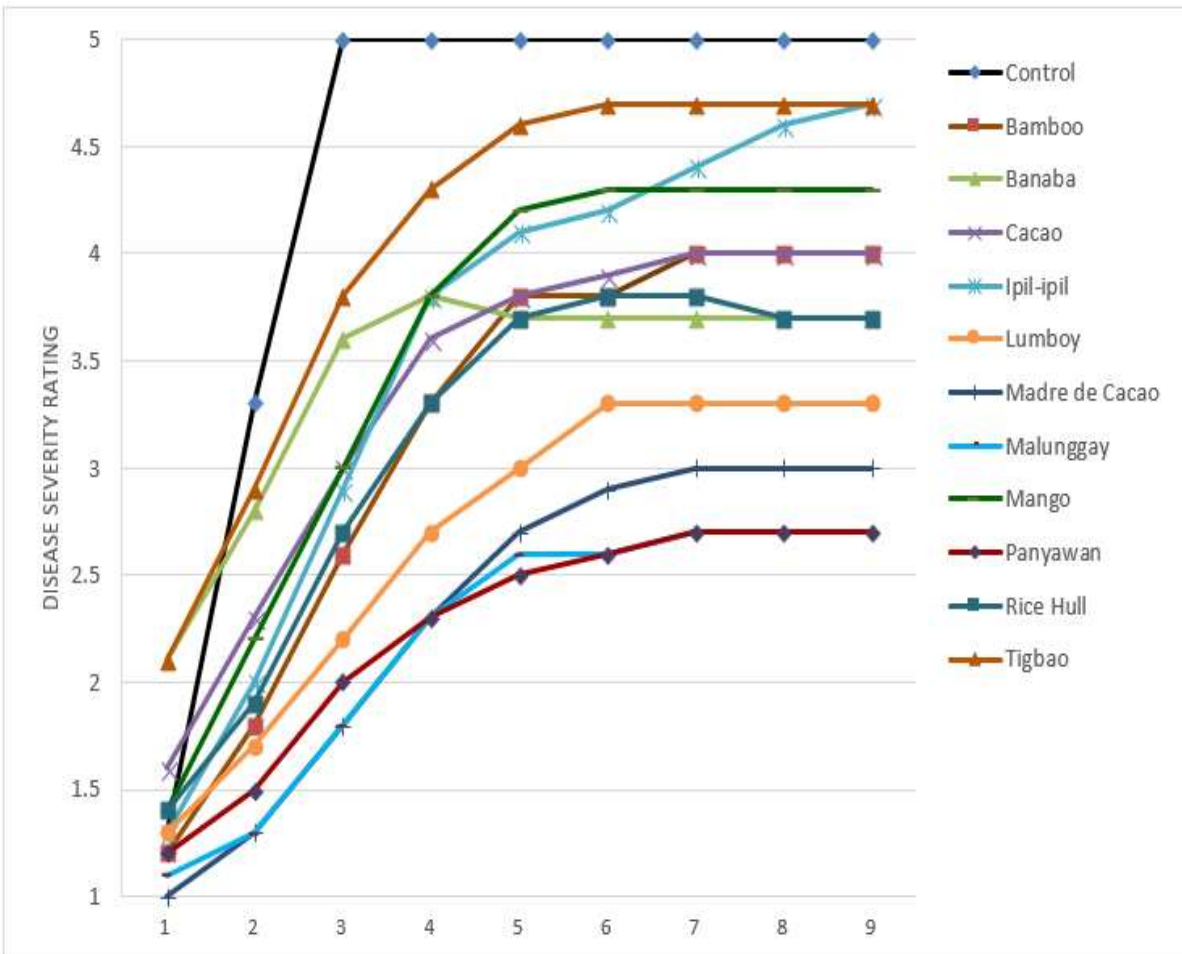

Figure 3. Disease severity rating in tomato inoculated with S. rolfsii as affected by wood vinegar against treatment 
Borines et al
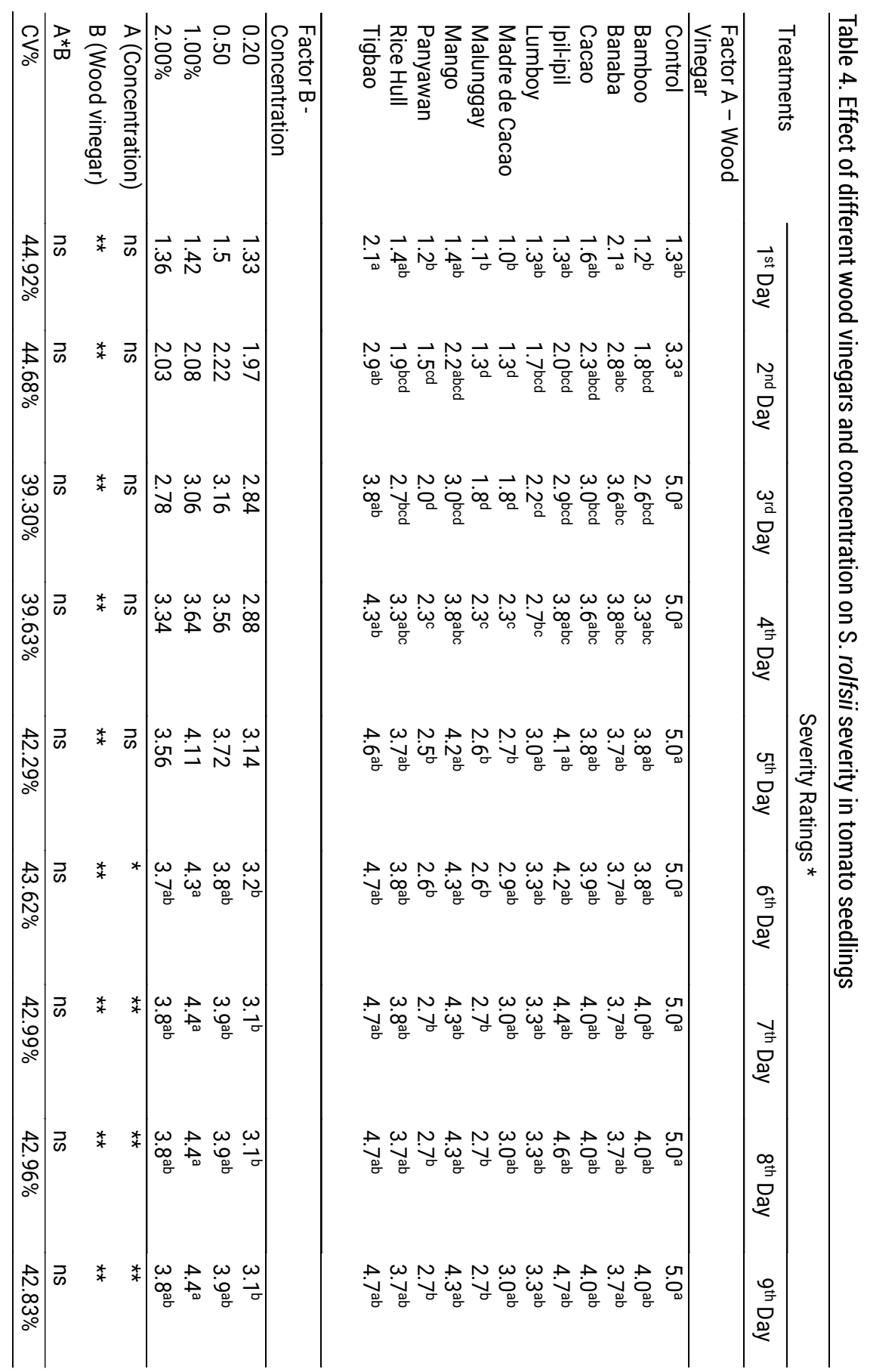
Efficacy of wood vinegars for the control of Sclerotium rolfsii affecting tomato

When the disease severity ratings were compared between the four concentrations used, all concentrations produced slower progress in disease severity rating over time compared to untreated plants. The lowest concentration, ie, $0.2 \%$ showed no inhibitory effect to $S$. rolfsii in vitro but when treated on plants, it produced the lowest disease severity rating (Table 4) and the slowest increase in disease progression over time (Figure 4). Which may be because it was also the least phytotoxic. The higher disease severity rating of the plants at the higher wood vinegar concentrations is probably due to the combined wilting effect of S. rolfsii infection and phytoxicity to tomato. It is therefore possible that aside from the direct antifungal effect of wood vinegar to $S$. rolfsii at higher concentrations, it can possibly induce the plant defenses against the pathogen at lower concentrations. This observation needs further research.

Wood vinegar is a by-product of charcoal making. Lou et al (2016) found that water-soluble organic compounds from pyrolysis residue containing low-molecular weight acids, macro and micro nutrients had been shown to be beneficial for plant growth. Plants treated with wood vinegar are claimed to be stronger, leaves greener and resistant to pests and diseases (FFTC accessed January 31 2018).

It is interesting to note that wood vinegars from malunggay and panyawan were the most effective in reducing sclerotium wilt severity in inoculated plants but these wood vinegars were not the most effective in inhibiting the fungus in vitro. The phytotoxicity data of these wood vinegars were not determined, however the low wilting severity rating in the in vivo test, suggests they are probably unlikely phytotoxic. Lumboy was one of the most effective in reducing the colony diameter of the fungus in vitro and was also one of the most effective in reducing the disease in vivo and was less phytotoxic than the other wood vinegars.

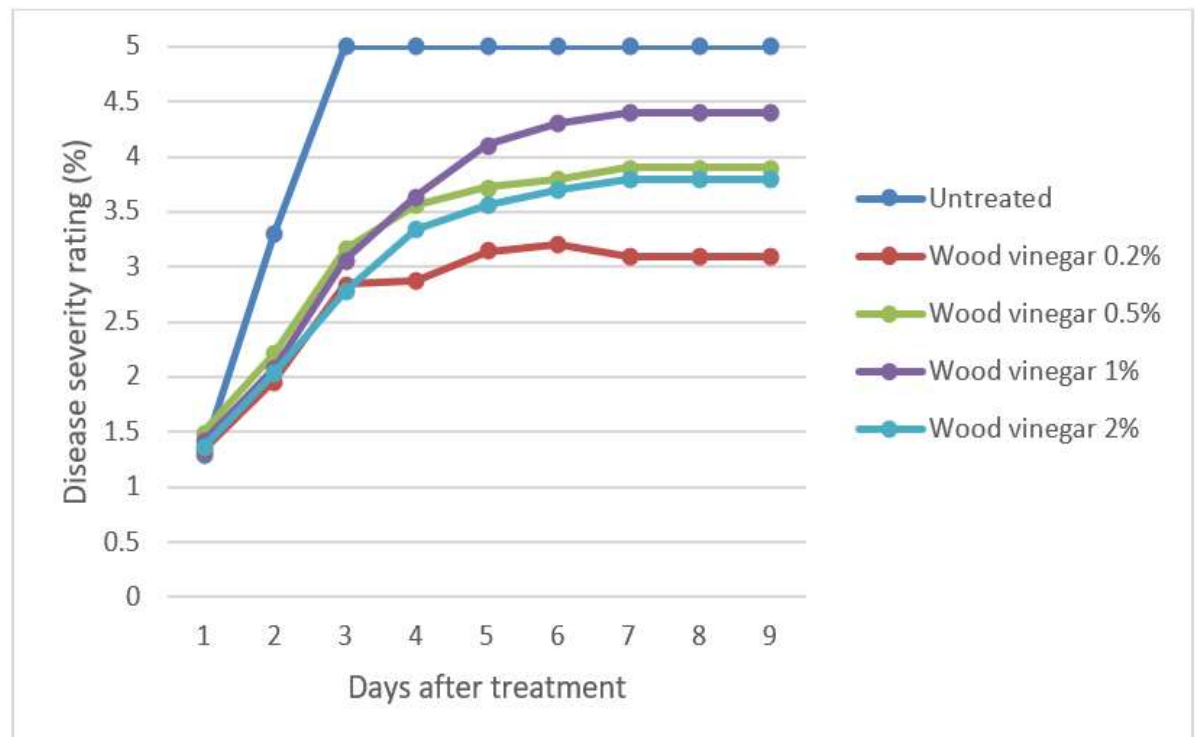

Figure 4. Disease severity rating in tomato inoculated with S. rolfsii as affected by concentration of wood vinegar 


\section{CONCLUSION AND IMPLICATION}

Eleven out of 17 wood vinegars evaluated showed direct inhibition to S. rolfsii in vitro. The eleven wood vinegars include wood vinegars from bamboo, banaba, cacao, caimito, ipil-ipil, lumboy, madre de cacao, malunggay, mango, panyawan and rice hull. These wood vinegars varied in their effectiveness in inhibiting the colony growth of S. rolfsii in vitro, with wood vinegar from ipil-ipil as the most inhibitory to the fungus followed by wood vinegar from lumboy. Wood vinegar from ipil-ipil however is the most phytotoxic to tomato. The wood vinegar from lumboy, however is promising since it is one of the most effective wood vinegars in reducing sclerotium wilt severity in inoculated seedlings and is one of the least phytotoxic. The wood vinegars from malunggay and panyawan, although they were not the most effective in reducing $S$. rolfsii colony growth in vitro were the most effective in reducing the progress in disease severity in inoculated tomato plants and retained their effectiveness for a longer time. Lower concentrations of the wood vinegars as a whole $(0.2 \%)$ was the most effective in reducing the sclerotium wilt severity over time, even though this concentration showed no direct inhibition to the fungus in vitro. This finding implies that wood vinegar may possess another mode of action in controlling the disease aside from the direct antifungal activity, and this could be as an inducer of resistance in plants against Sclerotium wilt. This however needs further research.

\section{ACKNOWLEDGMENT}

The authors would like to acknowledge the Regional Crop Protection Center (RCPC) Region 8 for the wood vinegars used in this study and the Australian Centre for International Agricultural Research (ACIAR), particularly the ACIAR-ICM Project for the research funds.

\section{REFERENCES}

Adfa M, Kusnanda AJ, Saputra WD, Banon CM, Efdi \& M Koketsu. 2017. Termiticidal Activity Toona sinensis wood vinegar Coptotermes curvignathus Holmgren. Rasayan Journal of Chemistry 10(4):1088-1093

Apai W and Thongdeethae S. 2001. Wood vinegar: new organic for Thai Agriculture. The 4th Toxicity Division Conference (pp166-169). Department of Agriculture

Burnette R. 2010. An Introduction to Wood Vinegar. ECHO Asia Notes. A Regional Supplement to ECHO Development Notes

Cai K, Jiang S, Ren C \& He Y. 2012. Significant damage-rescuing effects of wood vinegar extract in living Caenorhabditis elegans under oxidative stress. Journal of Agricultural and Food Chemistry 92:29-36

Calesterio RQ. (Accessed 2018). Implementation of Wood Vinegar Project in EV now underway. http://da08.da.gov.ph/index.php/media-resources/danews/249-implementation-of-wood-vinegar-project-in-ev-now-underway

Céspedes CL, Calderón JS, Lina L \& Aranda E. 2000. Growth inhibitory effects on fall armyworm Spodoptera frugiperda of some limonoids isolated from Cedrela spp. (Meliaceae). Journal of Agricultural and Food Chemistry 48:1903-1908 
Efficacy of wood vinegars for the control of Sclerotium rolfsii affecting tomato

Chuaboon W, Ponghirantanachoke N \& Athinuwat D. 2016. Application of wood vinegar for fungal disease controls in paddy rice. Applied Enviromental Research 38(3):77-85

Fengel D and Wegener G. 1984. Wood: Chemistry, ultrastructure, reactions. Walter de Gruyter, Berlin

Fereira DAF, Fereira MB, Favero S \& Carollo CA. 2013. Biological activity of sugarcane pyroligneous acid against Spodoptera frugiperda (J.E. Smith, 1797) (Lepidoptera: Noctuidae) larvae. African Journal of Biotechnology 12(43):6241-6244

FFTC (Food and Fertilizer Technology Center). Accessed January 31, 2018. WoodVinegar.http://www.fftc.agnet.org/library.php?func=view\&id=20110720 153306

Fouzia Y and Saleem S. 2005. Pathogencity of Sclerotium rolfsii on different crops and effect of inoculum density on colonization of mungbean and sunflower roots. Pakistan Journal of Botany 37(1):175-180

Hadizadeh I, Peivastegan B \& Hamzehzarghani H. 2009. Antifungal activity of essential oils from some medicinal plants of Iran against Alternaria alternata. American Journal of Applied Sciences 6(5):857-861

Hagner M, Kuoppala E, Fagernäs L, Tiilikkala K \& Setälä H. 2015. Using the copse snail Arianta arbustorum (Linnaeus) to detect repellent compounds and the quality of wood vinegar. International Journal of Environmental Research 9(1):53-60

Hwang YH, Matsushita Y, Sugamoto K \& Matsui T. 2005. Antimicrobial effect of the wood vinegar from Crytomenia japonica sapwood on plant pathogenic microorganisms. Journal of Microbiology and Biotechnology 15(5):1106-1109

Ilan C. 1975. Ultrastructural basis of Sclerotium rolfsii survival in soil. Microbial Ecology 2(3):194-200

Johnson M \& Subramanyam K. 2000. In- vitro efficiency of fungicides against stem rot pathogen of groundnut. Annals of Plant Protection Sciences 8: 255-257

Jung KH. 2007. Growth inhibition effect of pyroligneous acid on pathogenic fungus, Alternaria mali, the agent of Alternaria blotch of apple. Biotechnology and Bioprocess Engineering 12(3):318-322

Kim DH, Seo HE, Lee SC \& Lee KY. 2008. Effects of wood vinegar mixed with insecticides on the mortalities of Nilaparvata lugens and Laodelphax striatellus (Homoptera: Delphacidae). Animal Cells and Systems 12(1):47-52

Kokub D, Azam F, Hassan A, Ansar M, Asad M J \& Khanum A. 2007. Comparative growth, morphological and molecular characterization of indigenous Sclerotium rolfsii strains isolated from different locations of Pakistan. Pakistan Journal of Botany 39(5):1849-1866

Lou Y, Joseph S, Li L, Graber ER, Liu X \& Pan G. 2016. Water extract from straw biochar used for plant growth promotion: An initial test. Bioresources 11(1):249-266

Maurya S, Singh UP, Singh R, Singh A, \& Singh H B. 2010. Role of air and light in sclerotial development and basidiospore formation in Sclerotium rolfsii. Journal of Plant Protection Research 50(2):206-209

Mu J, Uehara T \& Furuno T. 2003. Effect of bamboo vinegar on regulation of germination and radicle growth of seed plants. Journal of Wood Science 49(3):262-270 
Nakai T, Kartal S, Hata N \& Imamura Y. 2005. Chemical characterization of pyrolysis liquids of wood-based composites and evaluation of their bio-efficiency. Journal of Building and Environment 42(3):1236-1241

Ninomiya Y, Zhang L, Nagashima T, Koketsu J \& Sato A. 2004. Combustion and DeSOx behavior of high-sulfur coals added with calcium acetate produced from biomass pyroligneous acid. Fuel 83(16): 2123-2131

Omara KJ. 2010. Manual for the identification of tomato species in tropics (pp2430). ASM press Washington D.C

Pangnakorn U and Kanlaya S. 2014. Efficiency of wood vinegar mixed with some plants extract against the housefly (Musca domestica L.). International Scholarly and Scientific Research \& Innovation 8(9):1064-1068

Pangnakorn U, Watanasorn S, Kuntha C \& Chuenchooklin S. 2009. Application of wood vinegar to fermented liquid bio-fertilizer for organic agriculture on soybean. The International Symposium on Go Organic 2009, The Approach of Organic Agriculture:New Markets, Food Security and a Clean Environment, 1921 August 2009, Bangkok, Thailand

Pangnakorn U, Uduye W \& Chuenchooklin S. 2007. Study on efficacy of wood vinegar for controlling insect pest and plant growth acceleration of Chinese kale (pp168-175). Proceedings 8th National Plant Protection Conference, 20-22 November, ISBN 978-974-09-4986-2

Palaiah P. 2002. Studies on variability in Sclerotium rolfsii Sacc. causing stem rot of groundnut (MS thesis) (pp73-78). University of Agricultural Sciences, Dharwad

Rahmat B, Pangesti D, Natawijaya D. \& Sufyadi D. 2014. Generation of wood waste wood vinegar and its effectiveness as plant growth regulator and pest insect repellent. Bioresources 9(4):6350-6360

Rakh RR, Raut LS, Dalvi M \& Manwar AV. 2011. Biological controls of Sclerotium rolfsii, causing stem rot of groundnut by Pseudomonas cf. monteilii. Recent Research in Science \& Technology 3(3):26-34

Rakmai J, Ovatlarnporn C \& Kaewnopparat S. 2009. Antibacterial properties against dermatitis bacteria of wood vinegars. Proceeding 35th Congress on Science and Technology of Thailand (STT35), 15-17 October 2009, Burapha University, Thailand

Saberi M, Sarpeleh A, Askary H \& Rafiei F. 2013. The effectiveness of wood vinegar in controlling Rhizoctonia solani and Sclerotinia sclerotiorum in green housecucumber. International Journal of Agricultural Research and Natural Resources 1(4):39-43

Udomporn P, Surasak W, Chumpon K \& Sombat C. 2010. Effects of wood vinegar and fermented liquid organic fertilizer on soybean (Srisamrong) cultivated under drought conditions. Journal of ISSAAS [International Society for Southeast Asian Agricultural Sciences] (Philippines) 16(2):67-73

Wani AH. 2011. An overview of the fungal rot of tomato. Mycopath 9(1): 33-38

Yatagai M, M. Nishimoto, K. Hor, T. Ohira and A. Shibata. 2002. Termiticidal activity of wood vinegar, its components and their homologues. Journal of Wood Science 48(4): 338-342

Zandersons J, Gravitis J, Kokorevics A, Zhurinsh A, Bikovens O, Tardenaka A \& Spince B. 1999. Studies of the Brazilian sugarcane bagasse carbonisation process and products properties. Biomass Bioenergy 17:209-219

Zulkarami B, Ashrafuzzaman M, Husni MO \& Razi IM. 2011. Effect of pyroligneous acid on growth, yield and quality improvement of rockmelon in soilless culture. Australian Journal of Crop Science 5(12):1508-1514 